\title{
PENYUSUNAN SISTEM INFORMASI AKUNTANSI TERKOMPUTERISASI BAGI KLINIK PRATAMA PANDU
}

\author{
Felisia $^{\text {1) }}$, Elsje Kosasih ${ }^{2)}$, Sylvia Fettry Elvira Maratno ${ }^{3)}$, \\ Tanto Kurnia ${ }^{4)}$, Chandra Ferdinand Wijaya ${ }^{5)}$ \\ ${ }_{1,2,3,4,5)}$ Universitas Katolik Parahyangan \\ E-mail: felisia.liu@unpar.ac.id
}

\begin{abstract}
Abstrak
Kegiatan pengabdian kepada masyarakat yang dilakukan oleh tim dosen Program Studi S1 Akuntansi Fakultas Ekonomi Unpar pada tahun 2018 merupakan kegiatan pengabdian bagi Klinik Pratama Pandu. Klinik Pratama Pandu bergerak dalam bidang pelayanan kesehatan bagi masyarakat menengah ke bawah, yang memiliki dua buah klinik, yaitu klinik umum dan klinik gigi. Saat ini, Klinik Pratama Pandu belum memiliki sistem pencatatan yang baik, sehingga ada beberapa hal yang dapat menyebabkan penurunan kualitas yang diberikan, seperti misalnya tidak adanya pencatatan mengenai persediaan obat-obatan. Tidak tersedianya pencatatan yang akurat dapat menyebabkan pelayanan kesehatan yang diberikan menjadi tertunda. Tim dosen Program Studi Akuntansi Unpar melakukan kegiatan pengabdian berupa penyusunan sistem informasi akuntansi secara terkomputerisasi. Hasil yang dicapai berupa program aplikasi komputer yang dibuat dengan menggunakan Microsoft Access untuk Klinik Pratama Pandu. Program aplikasi komputer ini dibuat sesuai dengan kebutuhan pengguna yang dibagi ke dalam 3 kelompok, yaitu untuk bagian administrasi, bagian bendahara, dan dokter. Program aplikasi komputer ini dapat digunakan untuk aktivitas pendaftaran pasien, pendaftaran rawat jalan, pendataan karyawan, pencatatan diagnosis dokter, pencatatan penerimaan, retur dan pencatatan persediaan obat-obatan, aktivitas penagihan pasien, pembayaran, pencatatan akuntansi beserta penyusunan laporan keuangan berupa laporan neraca, laporan laba rugi, laporan arus kas, buku besar untuk tiap akun. Setelah program aplikasi ini rampung, tim pengabdi mengadakan pelatihan bagi para pengguna di Klinik Pratama Pandu. Pelatihan ini diharapkan dapat membantu mitra dalam memudahkan pencatatan akuntansi dan data-data secara terkomputerisasi terkait kegiatan operasional sehari-hari dari Klinik Pratama Pandu.
\end{abstract}

Kata Kunci: pencatatan akuntansi, aplikasi komputer, sistem informasi akuntansi, laporan keuangan

\section{PENDAHULUAN}

Program Studi S1 Akuntansi Unpar melihat adanya kesempatan untuk membantu Klinik Pratama Pandu. Bantuan tersebut adalah berupa penyusunan program sistem informasi akuntansi terkomputerisasi. Sistem informasi akuntansi merupakan instrumen penting dalam penyusunan laporan. Laporan yang dihasilkan dapat memberikan informasi bagi para pengguna, seperti misalkan data pasien, data karyawan, rekapitulasi hasil diagnosis, serta prosedur bagi pasien untuk berobat mulai dari pendaftaran sampai dengan pelunasan pembayaran. Diharapkan melalui kegiatan pengabdian ini, Klinik Pratama Pandu dapat menerapkan program terkomputerisasi untuk membantu pencatatan akuntansi.

Mitra kami pada kegiatan ini berupa Klinik Pratama Pandu, sebuah lembaga sosial yang memberikan pelayanan kesehatan bagi masyarakat umum. Lokasi mitra berada pada Jalan Pandu no.4, Bandung. Klinik Pratama Pandu didirikan oleh Pastor A. Sudarno, OSC dan Ibu Nurhajati
Widjajakusuma pada tahun 1999. Klinik Pratama Pandu resmi beroperasi pada 11 Juni 2000 dengan nama Balai Pengobatan Pandu. Tahun 2008, Balai Pengobatan Pandu melakukan inovasi dengan membuka klinik kesehatan gigi. Pada tanggal 13 Juni 2012, Dinas Kesehatan Kota Bandung meresmikan kembali Balai Pengobatan Pandu dengan nama Klinik Pratama Pandu. Pelayanan kesehatan yang diberikan berupa pelayanan kesehatan umum dan kesehatan gigi untuk masyarakat menengah ke bawah.

Salah satu tujuan dibentuknya Klinik Pratama Pandu adalah untuk membantu meningkatkan kualitas kesehatan bagi masyarakat sekitar Gereja Pandu. Klinik Pratama Pandu memberikan pelayanan kesehatan dalam bidang kesehatan umum dan kesehatan gigi. Pelayanan kesehatan ditujukan bagi masyarakat menengah ke bawah.

Mitra kami bermaksud untuk melakukan pencatatan akuntansi secara terkomputerisasi. Dengan adanya bidang pelayanan kesehatan umum dan gigi yang dinaungi oleh Klinik Pratama Pandu, 
diperlukan pencatatan data dan transaksi yang akurat. Hal ini dapat dilakukan dengan bantuan aplikasi komputer. Tim dosen Program Studi S1 Akuntansi Unpar menyusun sistem informasi akuntansi yang kemudian dituangkan ke dalam pembuatan aplikasi komputer terkait sistem informasi akuntansi dari Klinik Pratama Pandu. Dengan adanya aplikasi komputer ini, diharapkan mitra dapat mencatat seluruh data, transaksi secara lebih akurat, sesuai dengan alur sistem informasi yang disarankan, sehingga pada akhirnya dapat berguna untuk meningkatkan kualitas pelayanan yang diberikan oleh Klinik Pratama Pandu kepada masyarakat sekitar.

Permasalahan yang dihadapi mitra pada dasarnya merupakan penjabaran dari kondisi mitra saat ini. Adapun permasalahan yang dihadapi mitra adalah sebagai berikut:

1) Mitra saat ini telah melakukan pembukuan sederhana, namun ada beberapa hal yang dapat disempurnakan seperti misalnya kartu untuk mencatat persedian obat-obatan.

2) Sistem informasi akuntansi yang dimiliki oleh mitra masih memerlukan perbaikan dalam beberapa hal.

3) Pencatatan akuntansi yang dilakukan mitra belum lengkap dan masih dilakukan secara manual.

4) Mitra memerlukan pencatatan akuntansi yang terkomputerisasi sehingga memperoleh informasi yang memadai untuk pengambilan keputusan.

Tim dosen Program Studi Akuntansi Unpar bermaksud untuk ikut berpartisipasi dalam peningkatan kualitas layanan yang diberikan Klinik Pratama Pandu, dalam bentuk penyusunan sistem informasi akuntansi secara terkomputerisasi. Dengan adanya kegiatan ini, diharapkan Klinik Pratama Pandu dapat mencatat seluruh transaksi yang terjadi dengan akurat melalui aplikasi komputer, sehingga dapat memudahkan pencarian data, penyusunan laporan, serta mengetahui perbandingan antara pendapatan dan biaya untuk melakukan pengambilan keputusan pengembangan klinik yang akhirnya akan meningkatkan kualitas layanan.

\section{METODE KEGIATAN}

Pengabdian ini dilakukan melalui metode kegiatan sebagai berikut:

1) Mengadakan pertemuan dengan pihak Klinik Pratama Pandu untuk membahas kebutuhan mitra dan memahami alur informasi akuntansi yang telah diterapkan Klinik Pratama Pandu.
2) Penyusunan sistem informasi akuntansi secara manual yang dapat menggambarkan alur informasi akuntansi Klinik Pratama Pandu.

Tim pengabdi menyusun alur sistem informasi akuntasi sesuai dengan kebutuhan mitra disertai dengan saran-saran perbaikan yang kemudian dituangkan ke dalam program aplikasi komputer untuk pencatatan data dan pelayanan kesehatan bagi Klinik Pratama Pandu.

3) Penyusunan program aplikasi komputer untuk pencatatan data dan pelayanan kesehatan.

Berdasarkan alur yang telah didiskusikan, tim pengabdi kemudian menyusun program aplikasi komputer untuk membantu mitra dalam pencatatan data pasien, obat, karyawan, dan pelayanan kesehatan yang diberikan.

4) Pelatihan dan pendampingan penggunaan program aplikasi komputer untuk pencatatan data dan pelayanan kesehatan.

Tim dosen memberikan pelatihan mengenai cara penggunaan program aplikasi komputer yang telah disusun. Pendampingan juga akan diberikan secara kontinu untuk membantu mitra memahami program aplikasi komputer yang telah disusun.

\section{HASIL DAN PEMBAHASAN}

Hasil yang dicapai dalam pengabdian ini terdiri atas:

1) Program aplikasi terintegrasi bagi Klinik Pratama Pandu.

Program aplikasi komputer ini dibuat sesuai dengan kebutuhan pengguna yang dibagi ke dalam 3 kelompok, yaitu untuk bagian administrasi, bagian bendahara, dan dokter. Program aplikasi komputer ini dapat digunakan untuk aktivitas pendaftaran pasien, pendaftaran rawat jalan, pendataan karyawan, pencatatan diagnosis dokter, pencatatan penerimaan, retur dan pencatatan persediaan obat-obatan, aktivitas penagihan pasien, pembayaran, pencatatan akuntansi beserta penyusunan laporan keuangan berupa laporan neraca, laporan laba rugi, laporan arus kas, buku besar untuk tiap akun.

Berikut ini merupakan tampilan muka dari program aplikasi terintegrasi yang dirancang sesuai dengan kebutuhan Klinik Pratama Pandu. 


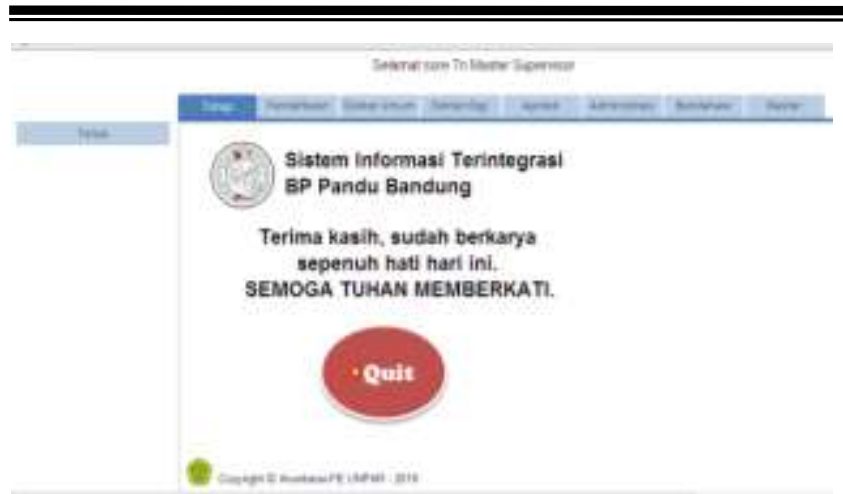

Gambar 1 Tampilan Muka Program

Program aplikasi terbagi atas beberapa modul, yaitu:

1) Tutup

Untuk menutup aplikasi.

2) Pendaftaran

Terdiri atas beberapa sub modul:

a) Pasien Baru

Sub modul ini berfungsi untuk mendata pasien baru yang datanya belum pernah ada atau belum dicatat sebelumnya.

b) Form Pendaftaran

Sub modul ini berfungsi untuk mendata pasien yang mendaftar untuk melakukan rawat jalan.

c) Form Penagihan

Sub modul ini berfungsi untuk mendata tagihan pembayaran kepada pasien setelah pasien diperiksa oleh dokter.

d) Laporan Kunjungan

Sub modul ini berfungsi untuk melihat daftar pasien yang telah melakukan rawat jalan, baik secara harian maupun bulanan.

e) Daftar Pasien

Sub modul ini berfungsi untuk melihat daftar pasien yang telah dicatat.

Berikut merupakan salah satu tampilan dari program aplikasi tersebut pada bagian modul Pendaftaran untuk pasien baru:

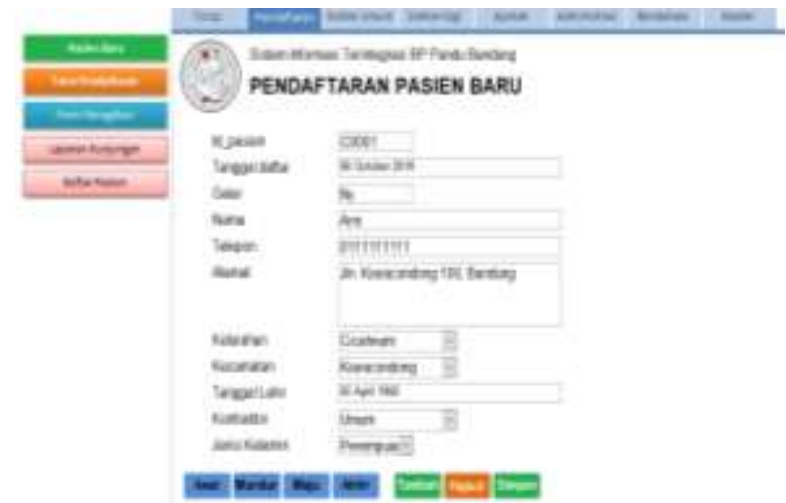

Gambar 2 Tampilan Modul Pendaftaran
Berikut merupakan salah satu tampilan dari program aplikasi tersebut pada bagian modul Pendaftaran Rawat Jalan Pasien:

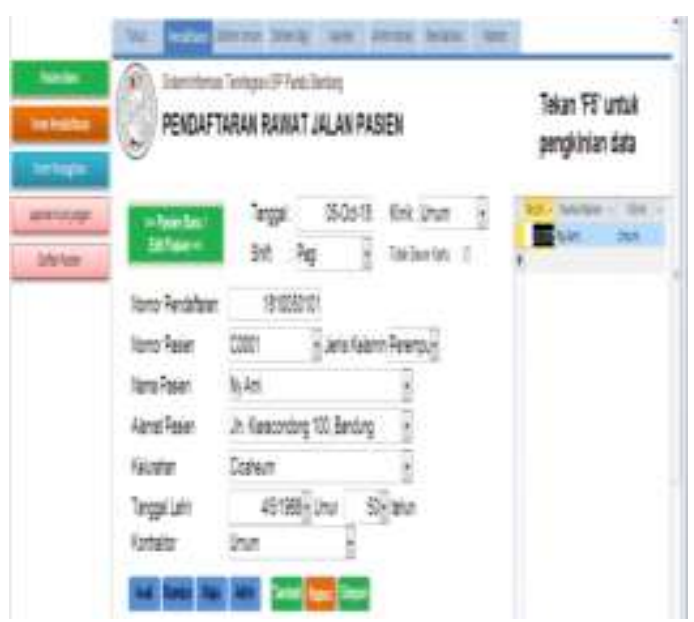

Gambar 3 Tampilan Modul Pendaftaran Rawat Jalan

Berikut merupakan salah satu tampilan dari program aplikasi tersebut pada bagian modul Pendaftaran sub modul Tagihan Pasien:

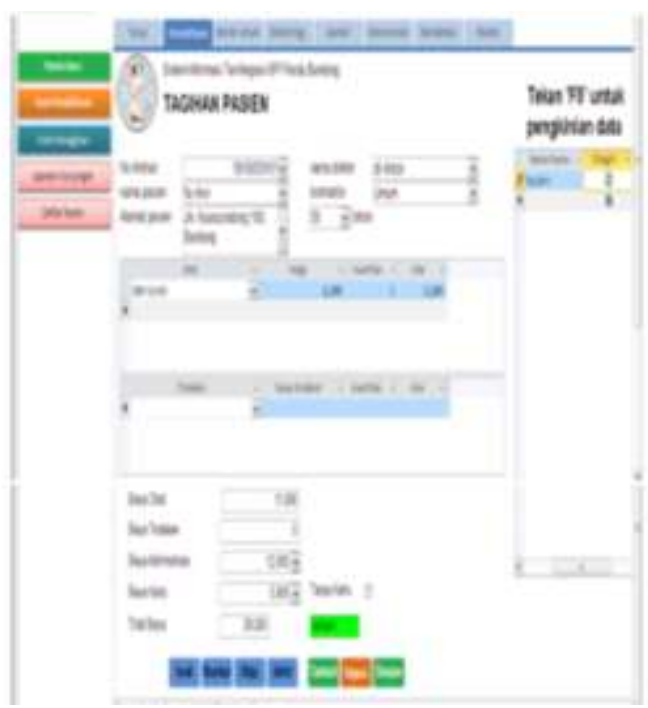

Gambar 4 Tampilan Modul Tagihan Pasien

3) Dokter Umum

Modul ini berfungsi untuk melakukan pendataan diagnosis, tindakan, dan obat yang diberikan oleh dokter umum kepada pasien rawat jalan.

Berikut merupakan salah satu contoh tampilan dari program aplikasi tersebut pada bagian modul Diagnosis Dokter Umum: 


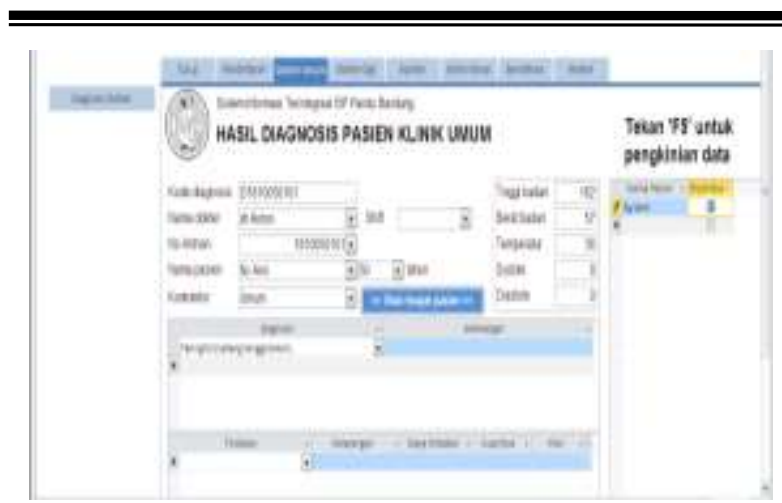

Gambar 5 Tampilan Modul Diagnosis Dokter

4) Dokter Gigi

Modul ini berfungsi untuk melakukan pendataan diagnosis, tindakan, dan obat yang diberikan oleh dokter gigi kepada pasien rawat jalan.

Tampilan dari modul Diagnosis Dokter Gigi mirip dengan tampilan dari modul Diagnosis Dokter Umum.

5) Apotek

Terdiri atas beberapa sub modul:

a) Data Obat

Sub modul ini berfungsi untuk mendata obat, baik namanya, indikasi, kemasan, serta bentuk sediaannya.

b) Penerimaan Obat

Sub modul ini berfungsi untuk mendata penerimaan obat.

c) Retur Obat

Sub modul ini berfungsi untuk mendata retur atas obat yang telah diterima.

d) Stok Opname

Sub modul ini berfungsi sebagai formulir untuk mendata stok opname.

e) Daftar Obat

Sub modul ini berfungsi untuk melihat daftar obat yang telah didata pada bagian Data Obat.

f) Form Stok Opname

Sub modul ini berfungsi untuk melihat data stok opname.

g) Laporan Stok Opname

Sub modul ini berfungsi untuk menampilkan laporan stok opname.

h) Laporan Penerimaan / Pemakaian Obat Sub modul ini berfungsi untuk melihat daftar obat yang telah diterima klinik atau yang keluar karena telah digunakan oleh dokter bagi pasien atau dibeli oleh pasien.
Berikut merupakan salah satu tampilan dari program aplikasi tersebut pada bagian modul Apotek sub modul Data Obat:

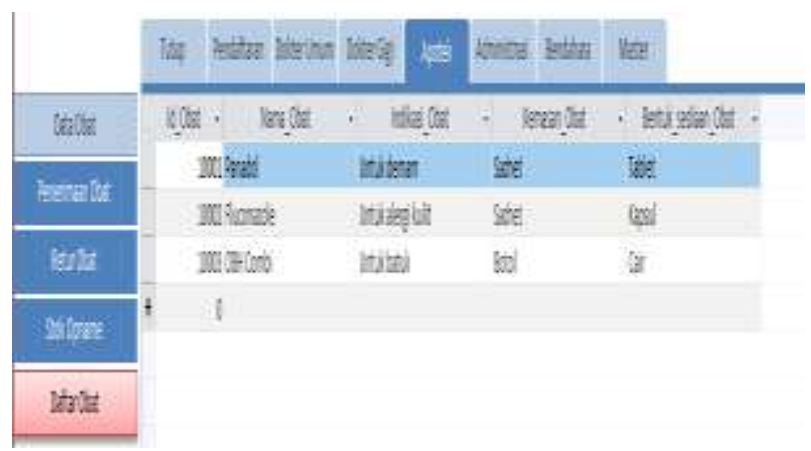

Gambar 6 Tampilan Modul Apotek - Data Obat

Berikut merupakan salah satu tampilan dari program aplikasi tersebut pada bagian modul Apotek sub modul Penerimaan Obat:

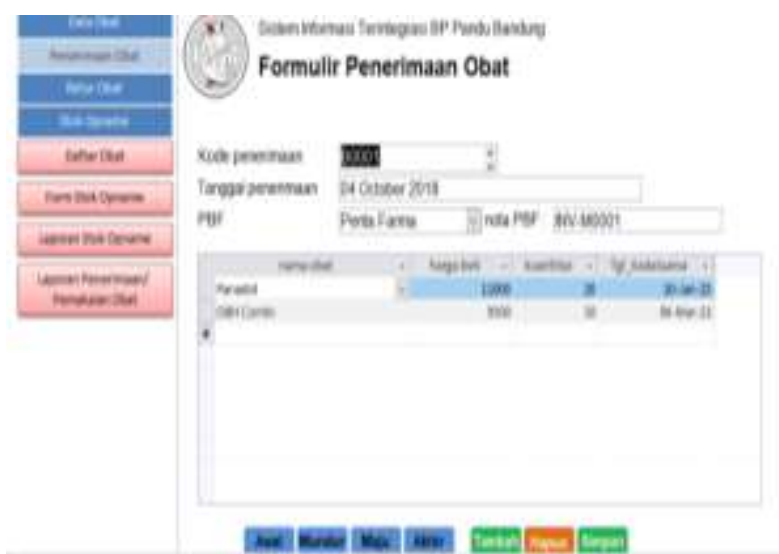

Gambar 7 Tampilan Modul Penerimaan Obat

Berikut merupakan salah satu tampilan dari program aplikasi tersebut pada bagian modul Apotek sub modul Retur Obat:

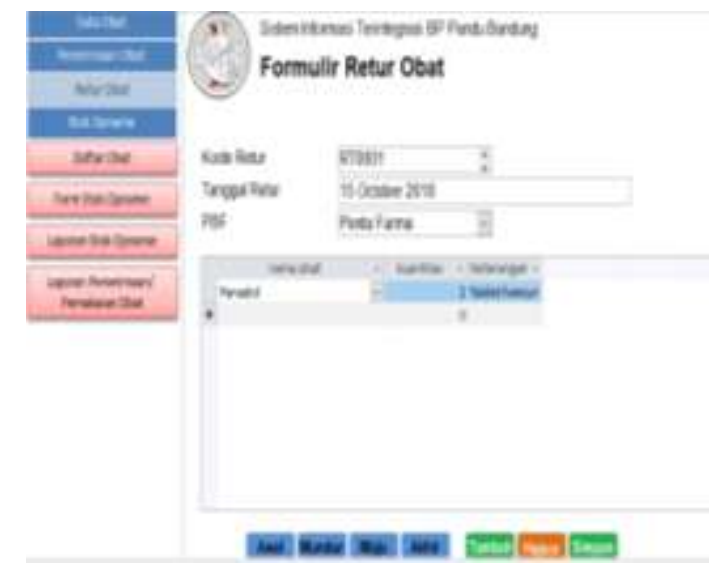

Gambar 8 Tampilan Modul Retur Obat 
6) Administrasi

Terdiri atas beberapa sub modul:

a) Data Karyawan

Sub modul ini berfungsi untuk mencatat data mengenai karyawan.

b) Data Kontraktor

Sub modul ini berfungsi untuk mencatat data kontraktor.

c) Data PBF

Sub modul ini berfungsi untuk mencatat data pemasok.

d) Data Diagnosis JKN

Sub modul ini berfungsi untuk mencatat data diagnosis JKN.

e) Data Kelurahan

Sub modul ini berfungsi untuk mencatat data kelurahan.

f) Data Profesi

Sub modul ini berfungsi untuk mencatat data profesi.

g) Data Shift

Sub modul ini berfungsi untuk mencatat shift dan waktu masing-masing shift.

h) Form Presensi Karyawan

Sub modul ini berfungsi untuk mendata kehadiran karyawan dalam suatu hari.

i) Daftar Diagnosis JKN

Sub modul ini berfungsi untuk melihat daftar diagnosis JKN yang telah diinput.

j) Daftar Kelurahan

Sub modul ini berfungsi untuk melihat daftar kelurahan yang telah diinput.

k) Daftar Profesi

Sub modul ini berfungsi untuk melihat daftar profesi yang telah diinput.

1) Daftar Shift

Sub modul ini berfungsi untuk melihat jumlah shift dan waktu masing-masing shift yang telah ditetapkan atau diinput.

m) Laporan LB1 Puskesmas

Sub modul ini berfungsi untuk melihat laporan penyakit yang telah ditangani Puskesmas.

Berikut merupakan tampilan dari program aplikasi tersebut pada bagian modul Administrasi:

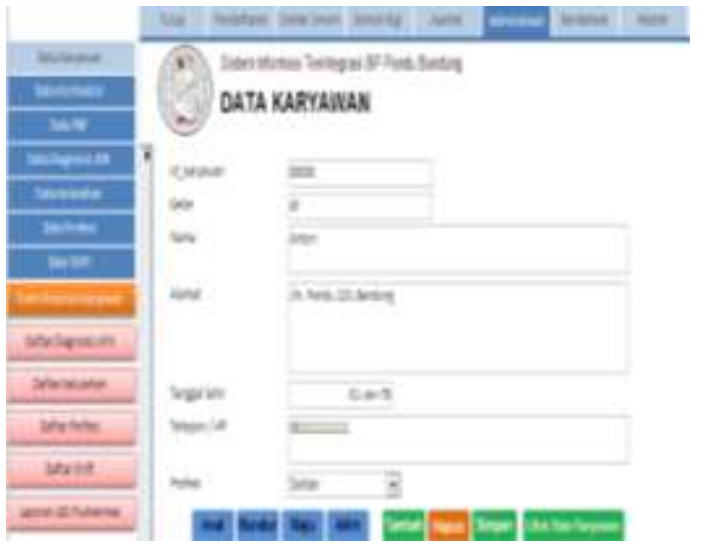

Gambar 9 Tampilan Modul Administrasi - Karyawan

7) Bendahara

Terdiri atas beberapa sub modul:

a) Data COA (Chart of Accounts)

Sub modul ini berfungsi untuk melihat daftar akun-akun untuk keperluan pencatatan akuntansi dan pelaporan keuangan.

b) Data Biaya

Sub modul ini berfungsi untuk menginput jenis dan besarnya biaya terkait pelayanan kesehatan.

c) Data Harga Obat

Sub modul ini berfungsi untuk menginput harga beli tertinggi dan harga jual dari obat yang ada.

d) Form Pembayaran Pasien

Sub modul ini berfungsi untuk mendata pembayaran yang dilakukan pasien.

e) Jurnal

Sub modul ini berfungsi untuk membuat jurnal pencatatan atas transaksi yang terjadi.

f) Laporan Keuangan

Sub modul ini berfungsi untuk melihat laporan keuangan beserta laporan terkait.

g) Daftar Biaya

Sub modul ini berfungsi untuk melihat daftar dan jenis biaya yang telah diinput.

h) Daftar Harga Obat

Sub modul ini berfungsi untuk melihat daftar harga obat yang telah diinput.

i) Laporan / Kuitansi Upah Karyawan Sub modul ini berfungsi untuk melihat laporan presensi karyawan dan kuitansi untuk keperluan pembagian honor karyawan selama periode waktu tertentu. 
j) Laporan Keuangan Kontraktor Sub modul ini berfungsi untuk melihat laporan kontraktor harian atau bulanan selama periode waktu tertentu.

Berikut merupakan tampilan dari program aplikasi tersebut pada bagian modul Bendahara bagian Input Jurnal:

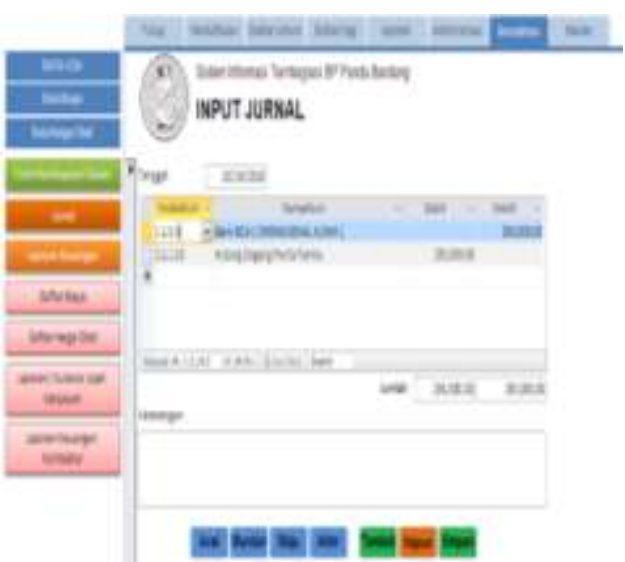

Gambar 10 Tampilan Modul Bendahara - Jurnal

Berikut merupakan tampilan dari program aplikasi tersebut pada modul Bendahara bagian Laporan Keuangan:

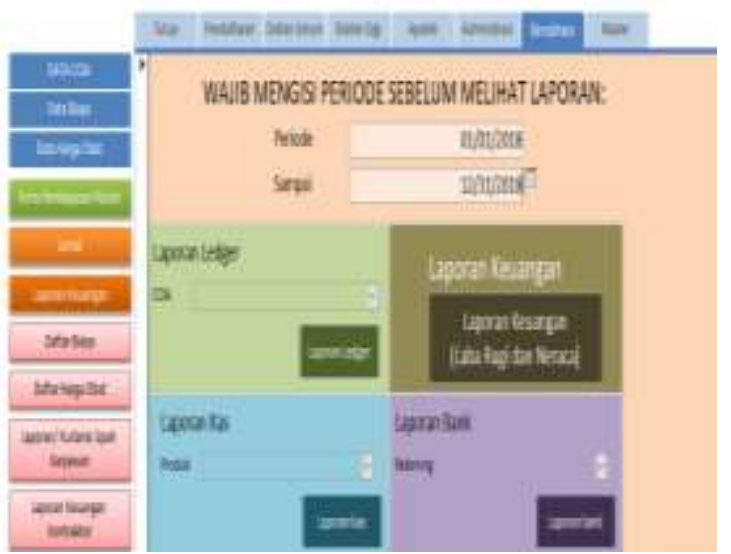

Gambar 11 Tampilan Modul Bendahara Laporan

8) Master

a) Master Menu Karyawan

Sub modul ini berisi mengenai data master karyawan.

b) Master Menu

Sub modul ini berisi mengenai data master menu.

c) Master Honor

Sub modul ini berisi mengenai data master tarif honor untuk masing-masing profesi. d) Master Tindakan

Sub modul ini berisi mengenai data master jenis tindakan, beserta biayanya dan tarif dokter.

e) Daftar Honor

Sub modul ini berisi mengenai laporan yang menunjukkan daftar honor yang telah diinput pada master honor.

f) Daftar Tindakan

Sub modul ini berisi mengenai laporan yang menunjukkan daftar tindakan beserta tarifnya yang telah diinput pada master honor.

2) Manual book mengenai langkah-langkah penerapan dari program aplikasi Klinik Pratama Pandu.

Manual book ini berisi mengenai petunjuk penggunaan dari aplikasi komputer terintegrasi bagi pihak Klinik Pratama Pandu. Keberadaan manual book ini diharapkan dapat mempermudah pihak Klinik Pratama Pandu dalam menggunakan program aplikasi ini untuk keperluan operasionalnya sehari-hari.

\section{KESIMPULAN}

Berdasarkan pengabdian yang dilakukan, maka dapat disimpulkan beberapa hal sebagai berikut:

1. Klinik Pratama Pandu telah melakukan pencatatan akuntansi dan data-data terkait kegiatan operasionalnya. Sebagian dari data tersebut masih dicatat secara manual.

2. Adanya kebutuhan bagi Klinik Pratama Pandu untuk melakukan pencatatan akuntansi dan datadata terkait kegiatan operasionalnya sehari-hari secara terkomputerisasi agar pengambilan keputusan dapat dilakukan secara akurat.

3. Tim pengabdi melakukan pertemuan dan diskusi dengan pihak Klinik Pratama Pandu. Diskusi tersebut membicarakan alur sistem informasi akuntansi dan alur bisnis dari klinik. Berdasarkan diskusi tersebut, tim pengabdi memberikan masukan mengenai alur sistem informasi dan masukan-masukan tersebut sekaligus dituangkan ke dalam program aplikasi komputer terintegrasi yang dapat digunakan pihak Klinik Pratama Pandu dalam pencatatan data akuntansi dan operasionalnya sehari-hari.

4. Hasil dari pengabdian ini adalah berupa program aplikasi komputer terintegrasi yang disesuaikan dengan kebutuhan mitra. Program 
ini dapat digunakan untuk aktivitas pendaftaran pasien, pendaftaran rawat jalan, pendataan karyawan, pencatatan diagnosis dokter, pencatatan penerimaan, retur dan pencatatan persediaan obat-obatan, aktivitas penagihan pasien, pembayaran, pencatatan akuntansi beserta penyusunan laporan keuangan berupa laporan neraca, laporan laba rugi, laporan arus kas, buku besar untuk tiap akun. Selain itu, pengabdian ini juga menghasilkan manual book yang dapat menjadi petunjuk penggunaan program aplikasi bagi pihak Klinik Pratama Pandu.

\section{REFERENSI}

Indrajani. 2017. Database Design Theory Practice and Case Study, Edisi 1. Jakarta: Elex Media Computindo.

Madcoms. 2016. Kupas Tuntas Microsoft Access 2016, Edisi 1. Yogyakarta: Andi.

Marshall, B. Romney \& Paul J. Steinbart. 2018. Accounting Information System, 14th ed. Boston: Pearson.

Weygandt, Jerry J., Paul D. Kimmel, \& Donald E. Kieso. 2015. Financial Accounting, 3rd ed. New Jersey: John Wiley \& Sons. 